\title{
REGIONALISM AND EMERGING MARKETS: An Analysis of Turkey's Trade with the BSEC and the EU
}

\author{
Ven Sriram* \\ Zeynep Bilgin"
}

\begin{abstract}
As the influence of regional economic blocs in world trade continues to grow, many countries, particularly from emerging markets, feel the pressure to join these regional agreements. The belief is that by joining them, the access to the member countries will bring economic opportunity - in terms of export opportunities and inward investment and help create political stability. Some countries, such as Turkey, are already members of more than one such preferential trading agreement and have the opportunity to join others. This paper reviews the relative importance of the European Union and the Black Sea Economic Cooperation organisation from the point of view of Turkey's trade with both blocs. The marketing and strategic implications of this for Turkish businesses are discussed.
\end{abstract}

\section{Background}

Political and economic changes taking place for the last decade in the world have created a "new world order". Here the second curve is said to belong to promising future emerging markets. ${ }^{1}$ However, the author believes that the transition will be slow since the first curve, i.e. countries with advanced economies, possess much of the revenues, most of the capital, and a disproportionate share of the consumption. But the second curve has the potential for growth because they are large in size, are committed to growth on a world scale, and are increasing their volume of international trade. But these countries have a long way to go, because in order to become a real second curve country, their income inequalities should be eliminated and the middle class should expand, accompanied by a rise in standard of living for

\footnotetext{
* Marmara University and University of Baltimore.

"* Marmara University
} 
all. ${ }^{2}$ The most rapid growth is expected to take place in countries moving away from socialist restrictions, among which Russia and others are expected to add significant millions to the rolls of the middle class. ${ }^{3}$

For many emerging markets, membership in a regional cooperation agreement has often meant the prospect for rapid economic development and heightened income and employment opportunities for their citizens. In this era of free trade initiated by the economically developed countries and supported by the World Trade Organization, many of these emerging economies are faced with increasing uncertainty about the ability of their industries and companies to compete successfully with world-class global competitors. This has become a reality particularly since their governments no longer heavily subsidize them nor are they cushioned any longer from foreign competition by the high walls of protectionism. As a result, and fearful of not being able to withstand the onslaught from higher quality, often cheaper, and better engineered products from developed-country exporters, many have been to try to attain membership into developedcountry unions hoping that the inward investment from companies from member countries will enable their own companies to "catch-up" much faster technologically. There is also the hope that membership in these blocs will also allow access to markets where their exports can be sent unimpeded. The experience of economically weaker European countries such as Greece, Portugal, and Spain shows that their entry into the EU enabled their economies to expand much more quickly. This also helps to explain the eagerness of many of the Central and Eastern European countries to join the EU or Latin American countries to join NAFTA. The benefits of economic integration include: larger potential markets for members, lower prices and better quality products due to cross-border competition, and lower distribution costs of selling to neighboring countries. ${ }^{4}$ Economic cooperation and mutual dependence can also lead to closer political ties, thus minimizing the threat of conflict in many unstable parts of the world. Akman and Dartan $^{5}$ have suggested that in the absence of effective and immediate multilateral solutions, countries may prefer regional integration in order to address their common concerns.

For emerging markets however, the process of achieving the entry criteria set by organizations such as the EU, and eventually being admitted as a fullfledged member, can take some time. As a result, another, perhaps a temporary and intermediate step for many, has been for them to form regional economic groups with their neighbors. 
Despite this apparently strong rationale of the benefits of such agreements ${ }^{6}$, the examples of successful ones in the developing world are few. Political instability and distrust combined with economic stagnation are the major reasons why many of these agreements in the developing countries, such as the South Asian Association for Regional Cooperation (SAARC) and ECOWAS, have struggled.

Interestingly, many countries already belong, or have the opportunity to belong, to more than one regional economic and/or political grouping. For example, India, a SAARC member, has recently been making overtures to the Association of South Eastern Asian Nations (ASEAN), some of whose members are also members of the Asia Pacific Economic Cooperation (APEC) organization. Turkey, a member of the Black Sea Economic Cooperation (BSEC) organization, is also a member of the Organization of the Islamic Conference (OIC) and has a customs union agreement with the EU. It has also clearly indicated its desire to become a full EU member.

This paper investigates the impact of Turkey's membership in the BSEC on its trade with member countries and how these trade patterns have changed since Turkey joined. This data is compared with Turkey's EU trade over the same period, in order to provide a comparison between an organization to which it already belongs on the one hand, and one it seeks to join, on the other. In addition to reporting export and import growth statistics, the paper also assesses Turkey's trade dependence on each of these two regional blocs.

This investigation may be particularly timely since many in Turkey feel that the EU is uncertain as to whether it wants Turkey as a member and several influential voices within the country have been arguing that the country also needs to examine the possibility of closer ties with other large neighbors such as Russia and Iran instead of focusing exclusively on EU membership. While the support for EU entry is very strong in Turkey, many feel that there is nothing to be lost by developing and expanding trade relationships with these other countries while waiting for the EU to decide on the timetable for Turkey's entry. 


\section{Black Sea Economic Cooperation Organization}

BSEC was established on June 25, 1992 with the aim establishing a free trade area in the region with free movement of goods, and services, and in the long run, capital and labor. ${ }^{7}$ The basics of the establishment of BSEC have not been properly defined in a consensus by neither the member nor third party countries. Hence it should viewed as a limited attempt at regionalization. ${ }^{8}$ In this sense it does not aspire to create a political and legal structure like the EU. The 11 member states of Albania, Armenia, Azerbaijan, Bulgaria, Georgia, Greece, Moldova, Romania, Russia, Ukraine and Turkey signed the Istanbul Declaration thus establishing the legal framework of this regional economic integration organisation. For the free trade aim to be realised, political stability in the region should be created with governments assuring certain incentives and guarantees to businesses to assure a healthy investment climate. ${ }^{9}$ The BSEC sees the private sector as playing a major role in the development of the member economies and therefore aims to provide an environment conducive for business. ${ }^{10}$ The region is of global economic and strategic importance. Economically, in 2000 , BSEC countries had more than 5.0 percent of total world trade amounting to US $\$ 300$ billion. Strategically, over 5.0 percent of the world population lives in the BSEC countries and many of them, such as Turkey, are geo-politically important given their proximity to Europe, the Middle East and Asia. BSEC members are also rich in strategic resources such as oil, coal and natural gas. ${ }^{11}$

The BSEC is structured to cooperate on different platforms and levels including: governmental, parliamentary, private enterprise, financial, and educational. ${ }^{12}$ In order to facilitate this cooperation, different bodies have been set up such as the Council of Ministers to aid inter-governmental exchange and the BSEC Business Council, which is made up of business representatives from private companies from the member states. The Black Sea Trade and Development Bank (BSTDB), established in 1999, provides banking and financial assistance whereas research centers and academic and university networks enable cooperation at the academic level.

Balkur ${ }^{13}$ stated that one of the principal aims of the BSEC's creation was to establish peace, security and harmony in the region. She also stated that the enhancement of economic, technological, and social development among member states and other countries was an important goal. Integration of 
efforts in terms of economy, science, technology and environmental issues ${ }^{14}$ was also a priority.

\section{Advantages of BSEC}

The economic benefits of BSEC can be grouped as follows: ${ }^{15}$ speeding up the economic improvement and ease of transition to the market economy, establishment of a healthy market environment with increased competition, technology transfer, attraction of foreign investment, and an increase in the competition power in the member countries.

There are several potential benefits for Turkey also through its membership in the BSEC $^{16}$ : there are significant trade complementarities in Turkey's exports (agricultural products, fisheries, training and consulting, apparel, technology etc.) and imports (e.g., natural gas from Russia). Turkey would also benefit from closer cooperation with its neighbours, with some of whom it already shares historical, cultural, and economic ties. Besides, Turkish and other investors should see the opportunities in BSEC as stepping stone to accessing other markets in the region. ${ }^{17}$ Beyond the benefits relevant for Turkey, other member states, particularly the smaller former Soviet republics (e.g., Armenia, Azerbaijan, Georgia, Moldova, Ukraine) and other previously isolated economies (e.g., Albania, Bulgaria, Romania), will also benefit from being part of the BSEC, as they will enjoy freer access to larger export markets.

In Turkey's case, the BSEC may represent a near-term alternative if its integration attempts with the EU take longer than expected. The BSEC market will also help offset the trade losses it suffered as a result of the postGulf War trade embargo on Iraq. Prior to this 1991 conflict, Iraq was one of Turkey's larger trading partners.

Of course, any investment climate can be negatively affected as long as local norms and values are neglected. Hence, regional factors should be considered for business negotiations and also at the marketing mix strategy development level. ${ }^{18}$

A shared economic system helps societies to form cultural universals. ${ }^{19}$ Provided that these factors are taken into account, the existence of panregional segments and the homogenisation of tastes among consumers in the member can be taken advantage of in creating scale economies in production 
and marketing. Also, given that some of the needs of these segments will be similar, imports from Turkey, with their lower production and distribution costs (when compared to EU suppliers), can be a viable alternative for other BSEC member countries.

\section{Barriers to Closer Cooperation}

At the time of the establishment of the BSEC, Dartan ${ }^{20}$ had identified several potential problems that may inhibit the effective functioning of the BSEC. These can be broken down into entry and operational barriers. The major entry barriers were: lack of permanent secretariat, political disagreements among some member countries (e.g., Georgia-Russia, Armenia-Azerbaijan, Greece-Turkey), hard currency availability, lack of legal infrastructure, discouraging foreign investment regulations, insufficient market data and weak environmental regulations. (The last two can also be seen as operational barriers). The key operational barriers were: lack of market knowledge, lack of advanced production technologies, unemployment due to need for skilled labor, and high levels of inflation. Also, as BSEC members such as Bulgaria, Romania, and Turkey attempt to join the EU, their commitment to the BSEC may weaken.

Ericson ${ }^{21}$ pointed out that the major structural problems of economic transition in the region were: difficulties in adapting to the market economy in terms of liberalization, privatization and restructuring attempts, lack of strong currency, difficulty in transitioning from the centrally-planned systems and inefficient resource use. He sees the transition to a private enterprise based free-market economy as a major challenge for many countries used to much more direct control by the state. Finally, in the case of Russia particularly and perhaps elsewhere as well, corruption and organized crime present significant barriers. Transparency International, a Berlin-based organization, ranked Russia as the fifth most corrupt country on their list. However, many emerging market countries are beginning to pass anti-corruption laws and take other measures to stop bribery and other corrupt practices. $^{22}$ Hence, the challenges arising from the absence of a healthy political system will be eliminated in the medium term and should thus make these markets more attractive to operate in.

While many of these barriers can appear to discourage firms from entering these markets, most are a natural outcome of the emerging market structure based on their dual economies and are common problems in the 
transition economies. These transition economies are the former Eastern Bloc countries and members of the former Soviet Union. ${ }^{23}$ In all these countries, a new global middle class is slowly emerging. However, in most cases these markets are not comparable to countries like China, India and Indonesia in terms of geographic size or population. ${ }^{24}$ The former Soviet Union countries around the Caspian Sea are undergoing economic and political transition to market economies and are therefore seen as starting emerging markets. ${ }^{25}$ Despite their prevailing challenges, they may well also provide promising opportunities. However, these opportunities should be evaluated with caution based on detailed analyses of macroeconomic data. By being a member of the EU customs union, Turkey is bound by EU rules regarding trade with non-EU members although Turkey has no power to influence these rules in Brussels. ${ }^{26}$

\section{Current Situation}

Many of the barriers identified by Dartan ${ }^{27}$ have been addressed while some of the others still prevail. As mentioned earlier, the BSEC has established several agencies and institutions that should facilitate cooperation among the member countries. These include the BSTDB established in 1999, the International Center for Black Sea Studies (ICBSS), a think tank set up in Athens in 1998 to carry out research in the fields of economics, industry and technology, and the BSEC Statistical Data and Economic Information Coordination Center operating in coordination with the Turkish State Statistical Institute. There is also now a Black Sea Universities Network (established in 1997 and involving 53 universities of the region) that will foster closer academic ties as well. ${ }^{28}$

\section{Impact of BSEC Membership on Turkish Trade}

One useful way to assess the impact of BSEC for Turkey is to examine how its imports and exports have changed during its membership in the BSEC. Tables 1 and 2 provide this data for Turkey for the period 19912001. The change in Turkey's intra-BSEC trade, compared to the change in Turkey's trade overall, is a good proxy measure of the degree to which the BSEC agreement has drawn Turkey closer to its fellow members.

As can be seen from Table 1, the percentage increase in Turkey's exports to and imports from BSEC, since its formation in 1992, is generally higher than the percentage increase in total exports and total imports on a yearly 
basis. The change from 1991 to 1992 appears to be disproportionately high both for BSEC export and imports due to the fact that 1992 data incorporates trade figures for all the member states whereas the 1991 data for BSEC was available for and limited to only four member countries. The impact was primarily observed for Turkish exports after 1993. This can be a result of the close ties developing within the region, stimulated also by the privatization and economic liberalization attempts started in most of the member countries. With the exception of the $1997-99$ period, Turkey's exports to the region grew faster than the overall growth in its exports. Figures for 2000 and 2001 indicate that the 1997-99 trend appears to have been reversed. Similarly, the growth in Turkey's imports from the region is generally higher than its overall import growth and in years where BSEC imports have declined, the decrease has been less than the decrease in total imports. This reflects that since its establishment, the share of BSEC in Turkey's total international trade has been increasing, indicating that the region has become an attractive market for business operations.

Among the member states, Russia is Turkey's largest trading partner with 3\% of Turkey's overall exports going to that country. Exports to Russia increased by $13.8 \%$ in 1993 and showed increases of $64.3 \%, 50.9 \%, 22.1 \%$, and $36.0 \%$ for each year from 1993 to 1997 respectively. The dramatic decrease in BSEC exports between 1997 and 1999 may be a result of the economic crises Russia was going through, particularly in 1998 and 1999. In that period, Turkish exports to Russia decreased by $34 \%$ in 1998 and $56 \%$ in 1999. In 2001 however, exports to Russia increased by $43.3 \%$ over 2000 . A similar pattern can be seen for Turkish imports from BSEC where imports from Russia decreased by $32.2 \%$ in 1994 and marginally in 1998. It should be pointed out that Turkey's 1994 economic crisis might also have contributed to decreases in BSEC and total imports in 1994 and its current economic crisis may account for the severe import decline in $2001 .^{29}$

As stated by Karataş, ${ }^{30}$ Armenia, Azerbaijan, Bulgaria, Georgia, Moldova, Romania, Russia, and Ukraine started their privatization attempts in 1992. Bulgaria reformed its banking system, and reforms in the Russia also included the introduction of the value-added tax, restructuring of the exchange rate system, and the liberalization of prices. These reforms have had a positive impact on Turkey's trade relations with these countries. 
Table 1: Percentage Change in Turkey-BSEC Trade (1991-2001)

\begin{tabular}{|l|l|l|l|l|l|l|l|l|l|l|}
\hline & $1992^{*}$ & 1993 & 1994 & 1995 & 1996 & 1997 & 1998 & 1999 & 2000 & 2001 \\
\hline $\begin{array}{l}\text { Exports } \\
\text { To BSEC }\end{array}$ & $\begin{array}{l}189.9 \\
(18.9)\end{array}$ & 3.6 & 7.4 & 48.2 & 19.8 & 30.2 & -14.4 & -32.9 & 9.1 & 13.1 \\
\hline Total Exports & 8.3 & 4.3 & 18.0 & 19.5 & 7.3 & 13.1 & 2.7 & -1.4 & 4.5 & 12.3 \\
\hline $\begin{array}{l}\text { Imports } \\
\text { From BSEC }\end{array}$ & $\begin{array}{l}318.9 \\
(36.9)\end{array}$ & 58.7 & -21.7 & 45.8 & -3.4 & 15.5 & -3.1 & -1.2 & 56.5 & -16.4 \\
\hline $\begin{array}{l}\text { Total Imports } \\
8.7\end{array}$ & 28.7 & -20.9 & 34.8 & 18.2 & 11.3 & -5.4 & -11.4 & 34.0 & -22.5 \\
\hline
\end{tabular}

Source: compiled based on data from www.foreigntrade.gov.tr; www.die.gov.tr; vildirimf@foreigntrade.gov.tr

* 1991 data for Turkish trade was only available for the following members of BSEC: Albania, Bulgaria, Greece and Romania. Therefore, numbers in parentheses in the tables have been calculated for these 4 countries only. To make appropriate comparisons for 1992, data is provided both for these 4 countries and all the BSEC members as well.

Table 2 reflects the share of BSEC trade in total trade of Turkey. From 1993 to 1997, there was a steady annual increase in exports to the region as a percentage of total Turkish exports. Department of Foreign Trade data show an increase in Russia's share of Turkey's BSEC exports from $43.7 \%$ in 1992 to $54 \%$ in 1997 . However in 1998 this share dropped to $41.6 \%$, a level lower than in 1992 and dropped even further in 1999 (to 27.1\%) and 2000 (to $27.2 \%$ ) and this may explain the lower reliance on the BSEC in 1999 and $2000^{31}$. 


\section{Table 2: Turkey's BSEC Trade as a Percentage of Total Trade (1991-2001)}

\begin{tabular}{|l|l|l|l|l|l|l|l|l|l|l|l|}
\hline & $1991^{*}$ & $1992^{*}$ & 1993 & 1994 & 1995 & 1996 & 1997 & 1998 & 1999 & 2000 & 2001 \\
\hline $\begin{array}{l}\text { Exports } \\
\text { To BSEC }\end{array}$ & $(2.55)$ & $\begin{array}{l}6.82 \\
(2.82)\end{array}$ & 6.77 & 9.04 & 11.21 & 12.51 & 14.40 & 12.00 & 8.17 & 8.53 & 8.50 \\
\hline $\begin{array}{l}\text { Imports } \\
\text { From } \\
\text { BSEC }\end{array}$ & $(1.98)$ & $\begin{array}{l}7.62 \\
(2.53)\end{array}$ & 9.40 & 9.31 & 11.20 & 8.86 & 9.20 & 9.43 & 10.53 & 12.29 & 13.80 \\
\hline
\end{tabular}

Source: compiled based on data from www.foreigntrade.gov.tr; www.die.gov.tr; yildirimf@foreigntrade.gov.tr

Also, imports from the BSEC countries improved after the establishment of the organisation. Turkey's principal import from Russia is natural gas. During Russia's economic crises, imports from Russia were still at a high level because this natural resource is now used in Turkey both in homes and in the industry. Thus, for each year between 1994 and 2000, imports from Russia account for approximately half of Turkey's BSEC imports. This may explain why Turkey's import share from BSEC has continued to grow.

\section{The European Union}

Economic necessities and political requirements in Europe after World War II were forcing European countries to find a solution in a world where they now had to cope with the dominance of USA and the then Soviet Union. They had learned throughout the war that physical boundaries of the states do not assure protection, but can rather be reasons for weakening and collapse. $^{32}$ So, six European countries, Germany, Italy, France, Belgium, Netherlands, and Luxembourg, started in 1950's with attempts to form a common market. On March 25, 1957 they signed the treaty in Rome which was the start for the formation of the European Economic Community EEC in $1958 .{ }^{33}$ The stepwise elimination of protectionist measures restricting trade, unification of the financial, economic and social programs of the member countries, assurance of parallalities in monetary policies, assurance of free movement of labor, development of healthy competitive 
environment, development of an investment fund to assure improvement in neglected areas of member countries were the basic aims articulated at the creation of the European Economic Community. ${ }^{34}$

The primary concern was to establish economic cooperation among the member states to form a common market, and in the future, a political integration. For that, the establishment of a customs union to assure free movement of goods among the member states was foreseen. In the period 1958 to 1968 , developments related to the customs union were finalized. ${ }^{35}$ In 1970's England, Denmark and Ireland, in 1980's Portugal, Spain and Greece, and in 1990's Austria, Finland and Sweden joined the commmunity. ${ }^{36}$

Turkey's relations with European Union (EU) - then the European Economic Community (EEC) - go back to the 1963 Ankara Agreement enacted in 1964. With this agreement, Turkey had become an associate member of the EEC. The aim was to have Turkey as a full member in the long run. ${ }^{37}$ In March 1995, the Turkish and the European Foreign Ministers decided to implement the final phase of the Ankara Agreement to establish a customs union with Turkey. After more than 30 years, on January $1^{\text {st }}$, 1996, the customs union-related negotiations were finalized. The customs union between Turkey and the EU countries involves the elimination of all customs duties and the abolishment of all quantitative restrictions. The free movement covers industrial and processed goods, and excludes unprocessed agricultural goods. ${ }^{38}$ The changes taking place for Turkey should not only be considered to be limited to changes in the structure of the economy and trade. It should be expected that these changes also have an impact on the political, legal, and administrative structure as well as the social foundation of the country. ${ }^{39}$

The customs union is based on two main issues: abolishment of the customs for intratrade of the member countries and application of a common customs and trade policy toward countries outside the community. ${ }^{40}$ The dynamics of the customs union can be stated as follows: economies of scale, increased competition, improvements in terms of trade, and increased economic growth. By July 1968, the original six members had completed the elimination of tariff and quota restrictions among themselves, and also common external tariffs to countries outside the system were set. Although these tariff and quota changes have an effect on trade, empirical investigation of the economic consequences of the EC customs union is 
extremely difficult and problematic because it is virtually not possible to separate the impact of these from those of many other factors affecting trade flows. But several studies completed in the second half of 1970's reflected the fact that customs union had significantly altered the trade flows and was on the whole creating higher level of trade, particularly in manufacturing. ${ }^{41}$

In practice, the customs union was far from being complete. There are factors other than tariffs and quotas which act as serious impediments to trade. As stated by Lintner \& Mazey, ${ }^{42}$ non-tariff barriers to trade such as national preferences in public procurement, national preferences in private purchasing, differences in indirect taxation, monopolies and restrictive practices, differences in technical regulations and standards, frontier formalities, state subsidies for selected domestic sectors in each country, differing trade and aid policies towards third countries are the factors which directly displace trade rather than distort prices. So, as stated by Greider, ${ }^{43}$ although the original notion of the "common market" uniting Europe was to create economies of scale for the European producers and European governments seemed to be ideologically committed to the free trade, through the EU they try to apply a purposive system of selective protection and subsidy that relies on market leverage.

\section{Advantages of EU Relations for Turkey}

Turkey, along with many other Central and Eastern European nations, has sought EU membership for some time now. There are several strong and compelling reasons for this. As mentioned earlier, the examples of other countries that have joined are very encouraging. EU membership has meant rapid economic development for many of the weaker economies of Southern Europe after they joined. They were the recipients of development funds and infrastructure investment from the wealthier members. Their citizens were able to gain immediate access to employment opportunities in other parts of Europe and the free movement of labor enhanced the speed of knowledge transfer. Their domestic industries benefited from unfettered access to markets across the continent and new manufacturing and technology investments flowed in due to their attractiveness as lower cost bases of production. Also, unlike many of the other attempts at regionalism, the economic stability and political maturity of the EU countries has been a big factor in the success of the union. For Turkey, the economic and political stability of the EU compared to the BSEC for example, makes it a much more attractive organization to join in the near term. Many of 
Turkey's largest trading partners, such as Germany, UK, Italy, and France are EU members.

The changes taking place bring new challenges for Turkey and create a new atmosphere between Turkey and EU. It is important to note that Turkey is the only country in the customs union without EU membership. The benefits of the customs union for Turkey were expected to be several. For business, higher productivity based on competition, competitiveness with global products, and partnerships with foreign investors. For consumers, access to better quality products, price advantages based on competition, access to higher creativity of manufacturers, and availability of higher technology products. ${ }^{44}$ But for all these benefits to accrue, Turkey had to achieve full compliance with the common regulations for imports and exports and the foreign trade regime, and sign similar agreements with countries with which EU had concluded voluntary restraint agreements. ${ }^{45}$ Besides, full adaptation was to be assured in terms of intellectual property rights. $^{46}$

\section{Obstacles in Turkey- EU Relations}

While opinion polls in Turkey consistently show that percentage of the population that objects to EU membership is a minority, many in the country share some of the concerns about the EU. While few seriously question the economic benefits that will accrue from EU membership, there is some concern over whether the EU really wants Turkey to join. After all, Turkey would be the only non-Christian member and its membership would extend the EU's borders to politically unstable countries in the Middle East and Central Asia. Also, were it to join, Turkey would become the second largest member (after Germany) of the EU in terms of population and in 15 years, the largest, and thus could wield considerable political power in Strasbourg and Brussels.

A significant Turkish concern is the possible loss of sovereignty that may result as the EU countries will insist that certain legal and political changes be made in Turkey. Some, such as the reduction in the size of the state sector and fiscal controls, may be economically necessary although they can lead to short term political problems. Others such as changes in the law on the death penalty and Turkish support for Northern Cyprus are much more vexing. There is also the possibility that Turkish firms may not be able to compete successfully against major European multinationals were its borders 
completely opened although Turkey has gone some way in that direction since it entered into a customs union agreement with the EU in 1995.

Although the Turkish private sector has accepted the customs union, there is a deep concern about the likely negative impact on some industries, especially on those at the infant industry stage, due to the removal of existing protection against imports of European Union origin. Large companies with their mass production and variety of wide-scale marketing functions can easily adapt themselves to the competitive structure and to the integration required for EU through the customs union. But problems occur for mid- and small-scale companies. The companies at a low productivity level are either forced to leave the market or to take serious corrective measures. ${ }^{47}$

Another obstacle to consider is that the EU restrictions on imports from non-member countries have to be applied by Turkey as well, as a consequence of its customs union membership.

\section{Impact of the EU on Turkish Trade}

The data presented in Table 3 show an interesting pattern in Turkey-EU trade. Turkey's exports overall have grown faster than exports to the EU for 7 of the past 10 years. 1995 was the year with the highest percentage increase in both overall and EU exports. It is interesting to note that with the exception of 1995, and in 1998 to a lesser extent, there have not been any dramatic changes in exports to EU unlike exports to the BSEC. This may be due to the fact that EU member countries do not have the economic volatility seen in Russia and other BSEC members. Also the EU markets are more or less saturated and intra-regional trade among the full members is more emphasized compared to trade with a non-member like Turkey, although Turkey is part of the customs union. 
Table 3: Percentage Change in Turkey-EU Trade (1991-2001)

\begin{tabular}{|l|l|l|l|l|l|l|l|l|l|l|}
\hline & 1992 & 1993 & 1994 & 1995 & 1996 & 1997 & 1998 & 1999 & 2000 & 2001 \\
\hline $\begin{array}{l}\text { Exports } \\
\text { To EU }\end{array}$ & 8.0 & -4.3 & 13.6 & 28.3 & 4.3 & 6.1 & 10.2 & 6.3 & 1.1 & 10.8 \\
\hline $\begin{array}{l}\text { Total Exports } \\
\text { Imports } \\
\text { From EU }\end{array}$ & 8.3 & 4.3 & 18.0 & 19.5 & 7.3 & 13.1 & 2.7 & -1.4 & 4.5 & 12.3 \\
\hline Total Imports & 8.7 & 28.7 & -20.9 & 34.8 & 18.2 & 11.3 & -5.4 & -11.4 & 34.0 & -22.5 \\
\hline
\end{tabular}

Source: compiled based on data from www.foreigntrade.gov.tr; www.die.gov.tr

In terms of imports, for 5 of the 10 years represented, EU imports have grown more, or decreased less, than Turkey's overall imports. Interestingly, the biggest spurt in imports also occurred in 1995-96, the period of customs union entry. It may be argued that the EU benefited more from than Turkey from Turkish membership in the customs union since Turkish imports from the EU increased by $37.2 \%$ whereas exports only rose by $4.3 \%$ in 1996 , the first year of Turkey's customs union membership. The fact that the value of Turkish imports (US $\$ 16.9$ from the EU and US $\$ 35.7$ billion overall) was much larger in 1995 than exports (US $\$ 11.1$ billion to the EU and US $\$ 21.6$ overall) makes the 1996 import increase even more dramatic.

The data in Table 4 can serve as a proxy for the importance of the EU to Turkey. A little over half of Turkey's exports go to the EU and a little less than half its imports come from the EU. EU import dependence peaked in 1996 with an almost 6 percentage point increase over 1995 and has decreased each year since. The figures for 2001 indicate that while overall imports declined in 2001, probably due to the economic crisis in Turkey, imports from the EU decreased even more sharply (Table 3). This may explain why the EU accounted for less than $45 \%$ of Turkey's imports in 2001 , a decrease of over 4 percentage points over 2000 . It is also interesting to note that the EU share of total Turkish exports and imports have declined each of the past 3 years. 
Table 4: Turkey's EU Trade as a Percentage of Total Trade (1991-2001)

\begin{tabular}{|l|c|c|c|c|c|c|c|c|c|c|c|}
\hline & 1991 & 1992 & 1993 & 1994 & 1995 & 1996 & 1997 & 1998 & 1999 & 2000 & 2001 \\
\hline $\begin{array}{l}\text { Exports } \\
\text { To EU }\end{array}$ & 54.05 & 53.92 & 49.51 & 47.69 & 51.20 & 49.73 & 46.64 & 50.04 & 53.97 & 52.24 & 51.56 \\
\hline $\begin{array}{l}\text { Imports } \\
\text { From EU }\end{array}$ & 47.02 & 46.59 & 47.14 & 46.91 & 47.22 & 53.04 & 51.22 & 52.43 & 52.62 & 48.82 & 44.75 \\
\hline
\end{tabular}

Source: compiled based on data from www.foreigntrade.gov.tr; www.die.gov.tr; yildirimf@foreigntrade.gov.tr

Table 5 summarizes the percentage point change in the BSEC and EU share of Turkey's trade (1991 data were excluded because data was available only for four BSEC members and the first year of complete data availability was 1992. Therefore 1993 data represents the change in the share of each region over 1992). As can be seen from this table, for 6 of the 9 periods, Turkey's exports to the BSEC and the EU moved in opposite directions. The most dramatic was 1999, where while the BSEC share of Turkey's exports declined by almost 4 percentage points over 1998, the EU's share increased correspondingly. For two of the periods, 1993 and 2001, the BSEC share remained almost the same while the EU share went down. Only in 1995 did the share of Turkish exports to the BSEC and the EU change in the same direction.

Table 5: Percentage Point Change in the Share of Turkey's Trade (1993-2001)

\begin{tabular}{|l|l|l|l|l|l|l|l|l|l|}
\hline & 1993 & 1994 & 1995 & 1996 & 1997 & 1998 & 1999 & 2000 & 2001 \\
\hline $\begin{array}{l}\text { Exports } \\
\text { To BSEC }\end{array}$ & -.05 & 2.27 & 2.17 & 1.30 & 1.89 & -2.40 & -3.83 & .36 & -.03 \\
\hline $\begin{array}{l}\text { Exports } \\
\text { To EU }\end{array}$ & -4.41 & -1.82 & 3.51 & -1.47 & -3.09 & 3.40 & 3.93 & -1.73 & -.68 \\
\hline $\begin{array}{l}\text { Imports } \\
\text { From } \\
\text { BSEC }\end{array}$ & 1.78 & -.09 & 1.89 & -2.34 & .34 & .23 & 1.10 & 1.76 & 1.51 \\
\hline $\begin{array}{l}\text { Imports } \\
\text { From EU }\end{array}$ & .55 & -.23 & .31 & 5.82 & -1.82 & 1.21 & .19 & -3.80 & -4.07 \\
\hline
\end{tabular}

Source: compiled based on data from www.foreigntrade.gov.tr; www.die.gov.tr

Import shares indicate a slightly different picture. As pointed out earlier, EU imports have been declining and it can be seen from Table 5 that in 2000 and 2001, 
share of imports from EU have declined sharply while imports from the BSEC have increased.

\section{Implications of Regionalism for Turkish Business}

The data presented in this paper has some interesting implications for Turkish businesses.

The higher growth rate of Turkey's BSEC trade when compared with its trade with the EU, albeit over a much smaller base, is a positive sign of risk diversification. As a nation, over $65 \%$ of Turkish exports in 2001 went to OECD countries (with $52 \%$ to the EU alone, ${ }^{48}$ whereas only $8.5 \%$ went to the BSEC (Table 2). Seven of Turkey's ten largest export markets are EU countries (the others are the US, Russia and Israel). Increasing exports to the BSEC therefore would help diversify risks for Turkish businesses that are heavily reliant on EU buyers. It should be borne in mind however, that exporting to BSEC countries other than Russia is also important. Russia is currently Turkey's sixth largest export market and accounts for a significant portion of Turkey's BSEC exports. This can be risky given the potential economic instability in Russia and the drop in BSEC export share from over $14 \%$ in 1997 to less than $9 \%$ in 2001 provides some evidence of this instability. The import data also appear to indicate a reduced dependence on the EU. While the EU, and Germany in particular, is Turkey's primary source of imports, the BSEC is gaining ground and Russia was the second largest import source (after Germany) in 2001. BSEC's share of Turkey's total imports has risen to almost $14 \%$ whereas the EU's has dropped to below $45 \%$ from its high of 53\% in 1996 . Imports from Russia may be more risky however because much of these imports are of natural gas, a product which has become a necessity due to the government policy of encouraging cleaner fuels. However, this policy may create a dependence on Russia as long as other alternatives supply sources such as Türkmenistan are not developed.

While EU membership is still, and arguably should be, Turkey's ultimate aim in terms of regional membership, the importance of the export opportunities in the BSEC should not be minimized. For many small and medium sized enterprises (SMEs) from Turkey, the highly competitive and saturated EU markets with their strong domestic companies may be hard to enter. On the other hand, underserved markets in the BSEC may represent attractive business opportunities since the entry costs, in terms of brand 
building and other marketing activities, may not be that high due to the absence of the major multinationals. Turkish companies who invest in these markets early will undoubtedly enjoy first-mover advantages that may help insulate them from the ravages of multinational competition when it does arrive. Bilgin ${ }^{49}$ suggests that these advantages could be in areas such as building corporate and product brand images, thereby creating loyalty in the long run. For SMEs, it will be easier to make Turkish brands known since advertising costs in BSEC countries will not be so high as to be unaffordable as in most of the EU, channel relationships and distribution arrangements will be in place and the companies will already be established before the arrival of major global competitors. For smaller Turkish businesses and new entrants to global markets, the BSEC can be a less demanding learning ground. The intense competition in the EU market may present too steep a learning curve for smaller companies. By entering and competing successfully in the generally smaller BSEC countries, they can hone the skills necessary to make them strong global players. The region can also serve as a jumping-off point to expand the global reach of Turkish firms to Central Asia and beyond.

Of course in order to benefit from the opportunities in these regional blocs, the mode of entry decision is crucial. Exporters will have to start giving serious thoughts to more committed forms of doing business such as licensing, franchising, and foreign direct investment. Clearly, the freer trade within the bloc will create economies of scale opportunities for Turkish companies. This becomes particularly relevant as regional segments are identified and companies Turkish companies are able to market standardised products to these segments.

It is important to emphasize that even though Turkey's sights are set on EU membership, it should not foreclose its other options. As mentioned earlier, the timetable for EU entry is uncertain and as the data from this study suggests, there is nothing to be lost by increasing trade with the BSEC. If anything, being active in the BSEC may help Turkish SMEs become more globally oriented as they will learn from their interaction and strategy creation in a developing international market environment. Market experience from an emerging area will contribute to the formation of regional strategies that will fit the individual, and regional where appropriate, country expectations. The experience of operating in several countries simultaneously in the BSEC will help Turkish firms to grow into 
true multinationals and even global firms as long as they can synthesise their learning.

\section{Limitations and Directions for Future Research}

The study confined itself to the examination of trade data. While export and import data does provide a valuable insight into the pattern of a country's trade, examination of investment data will also be useful. This will enable stronger conclusions to be drawn regarding the level of dependence. Clearly, since investing in a foreign market is riskier than merely exporting to it, investment data may provide a more accurate signal of commitment to a country and the perceptions of risk. Also, it was argued earlier that the benefits of regionalization include the closer political ties it creates between member countries. Much of this benefit will accrue from cross-border investment more than trade since the presence of investments in another country is more of a deterrent to conflict.

While this study investigated the change in Turkey's trade with the BSEC and the EU, future studies may wish to examine how Turkey's trade patterns have changed with the other multilateral groupings of which it is a member, such as the Organization of the Islamic Conference or even with individual countries such as the United States or Japan. All these opportunities for risk diversification should be examined as each presents their unique opportunities. Iraq was one of Turkey's larger trading partners before the 1991 Gulf War and resulting trade embargo on that country. Turkey has undoubtedly suffered as a result but the impact of such events can be minimized if a country is not too reliant on one region or country.

This study reflects a macro perspective for international business operations and addresses the issue of market selection in terms of market salience. Further research should focus on market entry and operational strategies at micro-marketing level. Studies on barriers to market entry for selected countries of the BSEC, where the trade volume of Turkey reflects a significant share, would help investors to overcome problems prior to developing operational strategies. While this study looked at macro-level trade statistics, future analyses should examine industry sector data and individual country data so that firms can identify areas of opportunity more clearly. For instance, much of the import from Russia is natural gas and while some BSEC members such as Russia and Azerbaijan are very important because of their natural resource endowments, their significance to 
Turkey can decline if these products are sourced instead from non-BSEC countries located in the Caspian Sea and the Persian Gulf. So future studies may want to examine more closely that type of products that are being traded, and whether these have easily available alternative supply sources, before any firm conclusions can be drawn on national dependence. The same is true for Turkish exports if the target countries can switch to other suppliers within the regional bloc or even indeed from outside the bloc. The nature of the preferential trading rules within the bloc will be a key determinant of the degree to which intra-bloc trade flourishes at the expense of trade from outside the bloc.

\section{Conclusion}

The establishment of BSEC was especially important for the region because of its filling a niche after the disintegration of the Soviet Union. The data suggests strongly that the BSEC region has become a very important one for Turkish trade and its relative importance has increased over the years. Over the same period of time, Turkey's reliance on the EU has diminished somewhat. For many emerging markets such as Turkey, while membership in developed-country blocs is the goal, there are other opportunities in emerging market agreements, such as the BSEC, that can be taken advantage of. At the firm level, BSEC membership will allow Turkish business, particularly the SMEs and those newer to global business, to hone their global skills and this will enable them to become viable competitors when they finally join EU. It will also give them access to less competitive markets where they may be able to establish themselves more easily than in the saturated markets of the West. At the national level, it can reduce the country's dependence on one regional market and thereby help diversify its trade risk and also create more opportunities. 


\section{Endnotes}

${ }^{1}$ Morrison, Ian (1996). The Second Curve - Managing the Velocity of Change. Ballantine Books: NY.

${ }^{2}$ Ibid.

${ }^{3}$ Ibid.

4 Bakhtiari, S. \& Daneshvar N. (2001). "The Challenges of Globalization and Regionalism for Developing Countries". Journal of International Marketing and Marketing Research 26 (2), 91-98.

5 Akman, M. Sait \& Dartan, Muzaffer (1998). "The Regionalism in the World Economy:

Novel Expectations from an Old Habit". Marmara Journal of European Studies 6 (1), 1-30.

6 Page, Sheila (2000). Regionalism Among Developing Countries. Macmillan Press/Overseas Development Institute, London.

${ }^{7}$ Aydın, Cemalettin (1996). "Karadeniz Ekonomik Ișbirliği Projesi”. Gümrük Birliği Sürecinde Türkiye. No.23 (May-June) : 124-143.;

Balkır, Canan (1993). Karadeniz Ekonomik İşbirliği Bölgesi (KEİB) - Ekonomik Bir Değerlendirme. TÜSİAD - Türk Sanayicileri ve Işadamlan Derneği Yayın No: TÜSİAD - T/93, 5-159 (May), Istanbul;

Dartan, Muzaffer (1992). "Karadeniz Ekonomik Işbirligi: Türkiye Lokomotif". Görüş (4), Istanbul.

${ }^{8}$ Akgün, Mensur (1994). Karadenizde Güvenlik ve Karadeniz Ekonomik İşbirliği: Türkiye Açısından Bir Değerlendirme. TÜSES Vakfi Yayınlanı (Şubat), İstanbul: 16.

9 Aydın, Cemalettin (1996). "Karadeniz Ekonomik Işbirliği Projesi”. Gümrük Birliği Sürecinde Türkiye. No.23 (May-June) : 124-143;

Dartan, Muzaffer \& Esra Hatipoğlu (2001). "Avrupa Birliği Genişleme Sürecinin Karadeniz Ekonomik İşbirliği Bölgesi'ne Etkileri”. Marmara Avrupa Arasstırmaları Dergisi - Journal of European Studies 9, No.2: 69-101.

${ }^{10}$ Black Sea Economic Cooperation Pact. Retrieved: November 2001, March 2002. WWW document: URL: http://www.photius.com/blackseafor/policy mfa tr.html

${ }^{11}$ Black Sea Economic Cooperation (BSEC) Organisation, Retrieved: November 2001 URL: http://www.treasury.gov.tr/english/ybsweb/blacksea.html. 
${ }^{12}$ Black Sea Economic Cooperation (1995). BSEC Handbook of Documents 1, Permanent International Secretariat, Istanbul;

Black Sea Economic Cooperation (BSEC) Organisation, Retrieved: November 2001;

URL: http://www.treasury.gov.tr/english/ybsweb/blacksea.html

${ }^{13}$ Balkır, Canan (1993). Karadeniz Ekonomik İşbirliği Bölgesi (KEIB) - Ekonomik Bir Değerlendirme. TÜSİAD - Türk Sanayicileri ve İşadamlan Derneği Yayın No: TÜSİAD - T/93, 5-159 (May), Istanbul.

${ }^{14}$ Ibid.

15 Aydın, Cemalettin (1996). "Karadeniz Ekonomik İşbirliği Projesi”. Gümrük Birliği Sürecinde Türkiye. No.23 (May-June) : 124-143.

${ }^{16}$ Dartan, Muzaffer (1992). "Karadeniz Ekonomik İşbirligi: Türkiye Lokomotif". Görüs (4), Istanbul;

Balkır, Canan (1993). Karadeniz Ekonomik İşbirliği Bölgesi (KEIBB) - Ekonomik Bir Değerlendirme. TÜSİAD - Türk Sanayicileri ve İşadamları Derneği Yayın No: TÜSİAD - T/93, 5-159 (May), Istanbul.

${ }^{17}$ Aydın, Cemalettin (1996). "Karadeniz Ekonomik İşbirliği Projesi”. Gümrük Birliği Sürecinde Türkiye. No.23 (May-June) : 124-143.

18 Schnitt, Peter (2001). "Geschäftsverhandlungen mit Fremden Kulturen". In: Trends im internationalen Management: Strategien, Instrumente und Methoden. 7194. Eds: Sonja Grabner- Kräuter \& Gerhard A. Wührer (eds.) Marketing Reihe, Institut für Handel, Absatz und Marketing - Johannes Kepler Universität Linz, Universitätsverlag Rudolf Trauner, Linz: Austria.

${ }^{19}$ Ferraro, Gary P. (1998). The Cultural Dimensions of International Business. Third Ed. Prentice Hall: NJ.

${ }^{20}$ Dartan, Muzaffer (1992). "Karadeniz Ekonomik İşbirligi: Türkiye Lokomotif". Görüss (4), Istanbul.

${ }^{21}$ Ericson, Richard E. (1995). "On Problems of Economic Transition in the Black Sea Region". Bogazici Journal - Review of Social, Economic and Administrative Studies 9 (1), 23-31. 
22 Schnitt, Peter (2001). "Geschäftsverhandlungen mit Fremden Kulturen". In: Trends im internationalen Management: Strategien, Instrumente und Methoden. 7194. Eds: Sonja Grabner- Kräuter \& Gerhard A. Wührer (eds.) Marketing Reihe, Institut für Handel, Absatz und Marketing - Johannes Kepler Universität Linz, Universitätsverlag Rudolf Trauner, Linz: Austria.

${ }^{23}$ Money, R.B. and Cotton, D. (2000). "The Response of the New Consumer to Promotion in the Transition Economies of the Former Soviet Block". Journal of World Business 2 (35);

Czinkota, Michael R. and Ronkainen I.A. (1996). Global Marketing. The Dryden Press, Harcourt Brace \& Co., Orlando, Florida.

${ }^{24}$ Morrison, Ian (1996). The Second Curve - Managing the Velocity of Change. Ballantine Books: NY.

${ }^{25}$ Bilgin, Zeynep (2001). "The Changing Market Structure in Starting Emerging Markets (SEMs) of Transition Economies - Marketing and Customer Perspectives". In: Trends im internationalen Management: Strategien, Instrumente und Methoden. 95-115. Eds; Sonja Grabner- Kräuter \& Gerhard A. Wührer (eds.) Marketing Reihe, Institut für Handel, Absatz und Marketing - Johannes Kepler Universität Linz, Universitätsverlag Rudolf Trauner, Linz: Austria.

${ }^{26}$ Dartan, Muzaffer \& Esra Hatipoğlu (2001). “Avrupa Birliği Genişleme Sürecinin Karadeniz Ekonomik İşbirliği Bölgesi'ne Etkileri”. Marmara Avrupa Araştırmaları Dergisi - Journal of European Studies 9, No.2: 69-101;

Akman, M. Sait (1996). "Gümrük Birliği Çerçevesinde Türk İthalat Politikası ve İthalat Rejimi”. Gümrük Birliği Sürecinde Türkiye.No.21-22 (Jan. - April): 48-59.

${ }^{27}$ Dartan, Muzaffer (1992). "Karadeniz Ekonomik İşbirligi: Türkiye Lokomotif”. Görüs

(4), Istanbul.

28 Turkish Treasury. Retrieved: November 2001. WWW document: URL http://www.treasury.gov.tr

${ }^{29}$ The Republic of Turkey, Prime Ministry, The Undersecretariat of Foreign Trade. Retrieved: November 2001, March 2002, WWW document: URL http://www.foreigntrade.gov.tr;

T.C. Başbakanlık Devlet İstatistik Ensititüsü (The Republic of Turkey Prime Ministry, State Statistical Institute). Retrieved: November 2001.WWW document: URL http://www.die.gov.tr 
${ }^{30}$ Karataş, Cevat (1995). "Discussion of Richard Ericson's Article". Boğaziçi Journal -

Review of Social, Economic and Administrative Studies 9 (1), 33-40.

${ }^{31}$ The Republic of Turkey, Prime Ministry, The Undersecretariat of Foreign Trade. Retrieved: November 2001, March 2002. WWW document: URL http://www.foreigntrade.gov.tr

${ }^{32}$ Deniau, Jean-François \& Gerard Druesne (n.a.). Ortak Pazar. Çev: Lerzan Özkale. Cep Üniversitesi, YeniYüzyıl Kitaplığı. İletişim Yayınları

${ }^{33}$ Ibid.

${ }^{34}$ Ibid.

${ }^{35}$ Deniau, Jean-François \& Gerard Druesne (n.a.). Ortak Pazar. Çev: Lerzan Özkale. Cep Üniversitesi, YeniYüzyıl Kitaplığı. İletişim Yayınlan;

Manisal1, Erol (1994). Avrupa Birliği'ne Alinmayan Türkiye'yi Gümrük Birliğinde Bekleyen Sorunlar. Araştırma Dizisi. Bağlam Yayınlanı: Ist.

${ }^{36}$ Manisalı, Erol (1994). Avrupa Birliği'ne Alınmayan Türkiye'yi Gümrük Birliğinde Bekleyen Sorunlar. Araştırma Dizisi. Bağlam Yayınlanı: Ist.

${ }^{37}$ Ibid.

${ }^{38}$ Duna, Cem \& Pars Kutay (1996). Where to with Customs Union? - Globalization, Macro-Regionalism and the EU. Intermedia: Ist;

Kaya, Mert (1996). "Gümrük Birliği İkliminin Türkiye'ye Getirdiği Yeni Rekabet Ortamı". Gümrük Birliği Sürecinde Türkiye.No. 24, (July-August): 19-21.

${ }^{39}$ Duna, Cem \& Pars Kutay (1996). Where to with Customs Union? - Globalization, Macro-Regionalism and the EU. Intermedia: Ist.

${ }^{40}$ Lintner, Valerio \& Sonia Mazey (1991). The European Community: Economic and Political Aspects. McGraw-Hill Book Company: London;

Manisall, Erol (1994). Avrupa Birliği'ne Alınmayan Türkiye'yi Gümrük Birliğinde Bekleyen Sorunlar. Araştırma Dizisi. Bağlam Yayınlañ: Ist.

${ }^{41}$ Lintner, Valerio \& Sonia Mazey (1991). The European Community: Economic and Political Aspects. McGraw-Hill Book Company: London.

${ }^{42}$ Ibid. 
${ }^{43}$ Greider, William (1998). One World, Ready or Not - the Manic Logic of Global Capitalism. Touchstone - Simon \& Schuster: NY.

44 "Birleşik Avrupa'ya Doğru". Egevizyon 3, p.17. in: Turkey and the European Union Relations in the Perspective of the Future Customs Union. Seminar on October 21-21, 1994 Boğaziçi University, Istanbul.;

Kılıç, Ramazan (1996). "Ekonomik Entegrasyon Teorisi”. Gümrük Birliği Sürecinde Türkiye. No. 24, (July-August): 68-74.

${ }^{45}$ Duna, Cem \& Pars Kutay (1996). Where to with Customs Union? - Globalization, Macro-Regionalism and the EU. Intermedia: Ist.

${ }^{46}$ Kaya, Mert (1996). “Gümrük Birliği İkliminin Türkiye’ye Getirdiği Yeni Rekabet Ortamı”. Gümrük Birliği Sürecinde Türkiye.No. 24, (July-August): 19-21.

47 İskender, C., A. Şeber \& R. Akıncı (1995). "Customs Union and Turkey's Competitiveness Opportunities." Rapor. TSKB A. Ş. Yayınları., (January);

Külünk, Metin (1995). "Gümrük Birliği'nin D1ş Ticarete Olan Etkileri”. Gümrük Birliği Sürecinde Türkiye. No. 19-20, (Sept.-Dec.): 57-60;

Şenyurt, Deniz (1996). "Küçük ve Orta Boy Isşletmelerin Gümrük Birliği Sonrasında Teşviki". Gümrük Birliği Sürecinde Türkiye.No. 21-22, (Jan. - April): 137-141.

48 The Republic of Turkey, Prime Ministry, The Undersecretariat of Foreign Trade. Retrieved: November 2001, March 2002. WWW document: URL http://www.foreigntrade.gov.tr

${ }^{49}$ Bilgin, Zeynep (2001). "The Changing Market Structure in Starting Emerging Markets (SEMs) of Transition Economies - Marketing and Customer Perspectives". In: Trends im internationalen Management: Strategien, Instrumente und Methoden. 95-115. Eds: Sonja Grabner- Kräuter \& Gerhard A. Wührer (eds.) Marketing Reihe, Institut für Handel, Absatz und Marketing - Johannes Kepler Universität Linz, Universitätsverlag Rudolf Trauner, Linz: Austria. 